HORTSCIENCE 27(10):1096-1099. 1992.

\title{
Postharvest Quality and Sensory Attributes of Organically and Conventionally Grown Apples
}

\author{
Jennifer R. DeEll and Robert K. Prange \\ Agriculture Canada Research Station, Kentville, NS, Canada B4N 1J5
}

\begin{abstract}
Additional index words. Malus domestica, 'McIntosh', 'Cortland', controlled atmosphere, firmness, soluble solids, titratable acids, sweetness, tartness, juiciness, offflavor, sensory scales
\end{abstract}

\begin{abstract}
Postharvest quality and sensory attributes of organically and conventionally grown 'McIntosh' and 'Cortland' apples (Malus domestica Borkh.) stored at 3C in ambient air or in controlled atmospheres were evaluated. Organically grown apples had higher soluble solids concentration than conventionally grown apples, while there were no significant differences in firmness or titratable acids content. Organically grown 'McIntosh' were perceived by sensory panelists as firmer than conventionally grown 'McIntosh' at harvest but not after storage, which may have been due to maturity differences. No significant differences were perceived in juiciness, sweetness, tartness, and off-flavor of apples at harvest or after storage.
\end{abstract}

Due to an increasing concern about possible human health risks and undesirable environmental effects associated with the use of synthetic chemicals in conventional apple production, some growers are interested in organic apple production, which does not involve the use of synthetic mineral fertilizers, pesticides, herbicides, fungicides, and growth regulators. Organic production relies on crop rotation, crop residues, manures, off-farm organic wastes, mechanical cultivation, mineral-bearing rocks, and biological pest control to maintain soil fertility and productivity, supply plant nutrients, and control insects, weeds, and other pests (Consumer and Corporate Affairs Canada, 1988).

Received for publication 9 Mar. 1992. Accepted for publication 21 May 1992. Contribution no. 2097. We thank K. McRae (statistician) for his advice and $\mathrm{H}$. Lightfoot, P. Harrison, and C. Burbidge-Boyd (technicians) for their assistance. The cost of publishing this paper was defrayed in part by the payment of page charges. Under postal regulations, this paper therefore must be hereby marked advertisement solely to indicate this fact.
Differences in pesticide application and soil fertility that are associated with organic production could dramatically alter the postharvest behavior of apples. However, there is a limited number of research reports on postharvest issues pertaining to organic production, and the results are generally conflicting.

Detailed analyses by Reinken (1987) of nutritive contents and sensory tests of fresh and stored "biodynamically" and conventionally grown apples did not indicate any differences due to production method. However, the conventional method of production produced slightly more Class 1 apples and fewer damaged fruit than the biodynamic method. Weissenborn and Dammann (1974) found supplementary organic fertilizers did not have consistent effects on the sugar and acid content of apples. Organic fertilizers were found to decrease the sugar content in 'Cox's Orange Pippin' and had no effect on 'Golden Delicious'. Both poultry and chicken manure increased the acid content of 'Cox's Orange Pippin', whereas cattle manure decreased and 
Table 1. Sensory attributes and reference material for panel training

\begin{tabular}{|c|c|c|c|}
\hline Attribute & $\begin{array}{l}\text { Scale } \\
\text { value }\end{array}$ & $\begin{array}{c}\text { Verbal } \\
\text { description }\end{array}$ & Reference material \\
\hline \multirow[t]{4}{*}{ Sweetness } & 1 & No sweetness & Distilled water \\
\hline & 3 & Slightly sweet & $\begin{array}{l}\text { Distilled water mixed } 50: 50(v / v) \text { with } \\
\text { apple juice }\end{array}$ \\
\hline & 5 & Moderately sweet & $\begin{array}{l}\text { Distilled water mixed } 50: 50(\mathrm{v} / \mathrm{v}) \text { with } \\
\text { apple juice plus } 3 \% \text { sucrose }(\mathrm{w} / \mathrm{v})\end{array}$ \\
\hline & 7 & Very sweet & $\begin{array}{l}\text { Distilled water mixed } 50: 50(\mathrm{v} / \mathrm{v}) \text { with } \\
\text { apple juice plus } 7 \% \text { sucrose }(\mathrm{w} / \mathrm{v})\end{array}$ \\
\hline \multirow[t]{4}{*}{ Tartness } & 1 & No tartness & Distilled water \\
\hline & 3 & Slightly tart & $\begin{array}{l}\text { Distilled water mixed } 50: 50(\mathrm{v} / \mathrm{v}) \text { with } \\
\text { apple juice }\end{array}$ \\
\hline & 4 & & $\begin{array}{l}\text { Distilled water mixed } 50: 50(\mathrm{v} / \mathrm{v}) \\
\text { with apple juice plus } 0.125 \% \text { malic } \\
\text { acid }(\mathrm{w} / \mathrm{v})\end{array}$ \\
\hline & 7 & Very tart & $\begin{array}{l}\text { Distilled water mixed } 50: 50(\mathrm{v} / \mathrm{v}) \\
\text { with apple juice plus } 0.375 \% \text { malic } \\
\text { acid }(\mathrm{w} / \mathrm{v})\end{array}$ \\
\hline \multirow[t]{2}{*}{ Off-flavor } & $\begin{array}{l}1 \\
2 \\
4\end{array}$ & No off-flavor & $\begin{array}{l}\text { Distilled water } \\
\text { Apple juice } \\
\text { Apple juice mixed 50:50 (v/v) with } \\
\text { forced McIntosh apple juicey }\end{array}$ \\
\hline & 6 & & Forced McIntosh apple juice \\
\hline \multirow[t]{2}{*}{ Firmness } & $\begin{array}{l}2 \\
5\end{array}$ & Very soft & $\begin{array}{l}\approx 1.2 \mathrm{~cm} \text { square of canned potato } \\
\text { Half of dry-roasted peanut }\end{array}$ \\
\hline & 8 & Very hard & Whole blanched almond ${ }^{v}$ \\
\hline \multirow[t]{3}{*}{ Juiciness } & 1 & No juiciness & Half of dry-roasted peanut \\
\hline & 3 & Slightly juicy & $\approx 1.2 \mathrm{~cm}$ square of canned potato \\
\hline & 5 & Very juicy & Whole canned mushroom ${ }^{u}$ \\
\hline
\end{tabular}

${ }^{2}$ Graves pure apple juice, Cobi Foods, Port Williams, N.S.

'McIntosh' apples held at room temperature in an air-tight plastic bag for 15 days to force ripening.

xAVON P.E.I. white potatoes whole, peeled and cooked, Canada Choice, Cobi Foods.

wPlanters unsalted peanuts, dry roasted without oil, Hersey Canada, Etobicoke, Ont.

`CO-OP whole blanched almonds, InterProvincial Cooperative Ltd., Saskatoon, Sask.

uJAS Choice Grade whole mushrooms, Jadsco Foods Intl., Montreal.

poultry manure increased the acid content of 'Golden Delicious'.

Our study was designed to investigate some postharvest quality and sensory attributes of organically and conventionally grown 'McIntosh' and 'Cortland' apples stored in refrigerated rooms in ambient air or in controlled atmospheres.

Prestorage treatment. Fourteen orchards located in the Annapolis Valley, N.S., were selected for harvesting in 1989 and 1990. Six of these orchards were 'McIntosh', three of which were managed conventionally and three organically according to the Canadian Organic Crop Improvement Assn. standards (Organic Crop Improvement Assn., 1989). The other eight orchards were 'Cortland', four managed conventionally and four organically. Orchards of similar age in each pair (one managed conventionally and one organically) were located as closely to one another as possible to limit microclimate and site differences (DeEll, 1991).

A $100-\mathrm{kg}$ sample of marketable preclimacteric (as indicated by starch test and internal ethylene concentrations) 'McIntosh' or 'Cortland' apples (>5.7 cm in diameter) was harvested from each orchard and precooled to $3 \mathrm{C}$ within $12 \mathrm{~h}$ of harvest. Two $20-\mathrm{kg}$ samples of precooled apples from each orchard were placed at random into one of six identical controlled-atmosphere chambers, in which $\mathrm{O}_{2}$ was reduced to $2.5 \%$ by $\mathrm{N}_{2}$ flushing within $24 \mathrm{~h}$ of harvest and $\mathrm{CO}_{2}$ was maintained at $4.5 \%$ with lime scrubbers. The $\mathrm{O}_{2}$ and $\mathrm{CO}_{2}$ concentrations were monitored daily, with adjustments being made when concentrations became $0.2 \%$ higher or lower than the desired concentrations. Another two 20-kg samples from each orchard were placed in $38-\mu \mathrm{m}$-thick perforated polyethylene liners in air storage to maintain the relative humidity (RH) at $94 \%$ to $96 \%$ without modification of the surrounding $\mathrm{O}_{2}$ or $\mathrm{CO}_{2}$ levels. One 20-kg sample from each orchard was used for initial measurements at harvest. Another 20-kg sample from each treatment was randomly removed after 4 months of storage and another after 8 months.

Poststorage analyses. At harvest and after 4 months of storage, the quality of apples from all seven orchard pairs and each storage regime was evaluated using a combination of physical and chemical tests in 1989 and 1990. Firmness, soluble solids concentration (SSC), and titratable acids content (TA) were measured immediately at harvest, after removal from storage, and again after 7 days at $20 \pm 1 \mathrm{C}$.

Fruit firmness was determined on a 10fruit subsample using a Ballauf penetrometer (Ballauf, Laurel, Md.) with an 11.1-mm-diameter tip to test opposite sides of the fruit after the peel had been removed. The resulting juice was measured for SSC using a hand-held temperature-compensated refractometer (Atago, Japan) and for TA by titrating a 2-ml juice sample with $0.1 \mathrm{~N} \mathrm{NaOH}$ using a semiautomatic Multi-Dosimat EP415 titrator (Metrohm AG, Herisau, Switzerland) to an endpoint of $\mathrm{pH} 8.1$ as indicated by phenolphthalein.

Since differences in firmness, SSC, and TA were observed in 1989 , sensory testing was conducted in 1990 to determine if these differences would be perceptible. To allow for a balanced design, sensory tests were conducted only on six orchard pairs (three 'McIntosh' and three 'Cortland') at harvest and for each storage regime after 4 months of storage. No sensory testing was conducted after 8 months of storage, as some air-stored samples were unacceptable for consumption.

Apples were evaluated by a sensory panel trained for the perceived intensities of sweetness, tartness, off-flavor, firmness, and juiciness using structured nine-point scales. Ten panelists, selected by their past performance on sensory tests, met for three 1-h training sessions. The sessions were designed to improve the panelists' ability to recognize, describe, and consistently quantify the sensory characteristics of apples. Along with practicing the rating of 'McIntosh' and 'Cortland' apples from both production methods, the panelists selected the order for evaluating the attributes and agreed upon reference materials (Table 1) for use in both defining the attributes and anchoring the intensity scales.

All testing was conducted in a climatecontrolled taste-panel room equipped with individual booths and white lighting. Apples were removed from cold storage $4 \mathrm{~h}$ before each taste-panel session and allowed to warm to room temperature $(20 \pm 1 \mathrm{C})$. At harvest, each panelist tasted three randomly ordered sets of apples for each cultivar. Each set consisted of two apples, one from each production method of a single orchard pair. Four apples removed from storage were presented in random order to each panelist at each tastepanel session. These four apples consisted of an air-stored and a CA-stored apple from each production method of a single cultivar. Thus, six panel sessions were required to test the three orchard replications of each cultivar.

At all panel sessions, an apple from each experimental unit was prepared for each panelist by halving the apple and using the blush side, cutting it in two and removing the skin and seeds. Each set of apples was prepared while the panelist waited. Apples were presented in white china bowls that were coded with three-digit random numbers. When flavor attributes were evaluated, panelists were asked to use unsalted crackers and distilled water between samples to remove any residual flavors from the mouth.

Statistical analyses. At harvest, cultivar and production method were factors, with orchard pairs being replicates. An additional experimental structure for storage was superimposed on the orchard samples. Each sample was subdivided into five parts; one part was used for initial measurements and the other four were randomly assigned to the four storage atmosphere $\times$ storage time combinations. There was no storage time factor for analyses of the sensory attributes, as they were not evaluated after 8 months of storage. The effect of panelist was also estimated for the sensory attributes. All data were analyzed statistically using analysis of variance procedures from Genstat 5 (Genstat 5 Committee, 1987). Only sources of vari- 
Table 2. Effects of production and storage method on the physical and chemical properties of 'Mclntosh' and 'Cortland' apples at harvest and 1 day after storage. Data are averages of 1989 and 1990 seasons.

\begin{tabular}{|c|c|c|c|c|c|c|c|c|c|c|c|c|c|c|c|c|c|}
\hline \multirow{3}{*}{$\begin{array}{l}\text { Source of } \\
\text { variation }\end{array}$} & \multicolumn{6}{|c|}{ Firmness (N) } & \multicolumn{6}{|c|}{ Soluble solids concn (\%) } & \multicolumn{5}{|c|}{$\begin{array}{c}\text { Titratable acids } \\
\text { (mg malic/100 ml juice) }\end{array}$} \\
\hline & \multirow[b]{2}{*}{ Initial } & \multicolumn{2}{|c|}{4 months } & \multicolumn{2}{|c|}{8 months } & \multirow[b]{2}{*}{ SEM $^{2}$} & \multirow[b]{2}{*}{ Initial } & \multicolumn{2}{|c|}{4 months } & \multicolumn{2}{|c|}{8 months } & \multirow[b]{2}{*}{ SEM $^{2}$} & \multirow[b]{2}{*}{ Initial } & 4 months & \multicolumn{2}{|c|}{8 months } & \multirow[b]{2}{*}{$\mathrm{SEM}^{\mathrm{X}}$} \\
\hline & & $\overline{\mathrm{Air}}$ & $\overline{\mathrm{CA}}$ & $\overline{\text { Air }}$ & $\overline{\mathrm{CA}}$ & & & Air & $\mathrm{CA}$ & Air & $\mathrm{CA}$ & & & Air CA & Air & $\mathrm{CA}$ & \\
\hline \multicolumn{18}{|l|}{ McIntosh } \\
\hline Organic & 74 & 50 & 68 & 41 & 63 & \multirow{3}{*}{1.3} & 11.9 & 11.8 & 12.4 & 11.2 & 12.0 & \multirow{3}{*}{0.18} & 923 & 575701 & 334 & 598 & \multirow{3}{*}{20.5} \\
\hline \multirow[t]{2}{*}{ Conventional } & 69 & 43 & 63 & 38 & 58 & & 11.1 & 10.8 & 11.2 & 10.2 & 11.0 & & 868 & 543660 & 306 & 509 & \\
\hline & \multicolumn{5}{|c|}{$\mathrm{SEM}^{y}=1.9$} & & \multicolumn{5}{|c|}{$\operatorname{SEM}^{\mathrm{y}}=0.34$} & & \multicolumn{4}{|c|}{$\mathrm{SEM}^{\mathrm{y}}=35.6$} & \\
\hline \multirow{2}{*}{ Cortland } & & & & & & \multirow{3}{*}{1.1} & & & & & & \multirow{3}{*}{0.15} & & & & & \multirow{3}{*}{17.6} \\
\hline & 80 & 56 & 72 & 52 & 68 & & 12.0 & 12.5 & 13.0 & 11.5 & 12.5 & & 780 & $520 \quad 638$ & 313 & 549 & \\
\hline \multirow[t]{2}{*}{ Conventional } & 79 & 53 & 72 & 50 & 69 & & 11.6 & 11.5 & 12.6 & 10.5 & 11.7 & & 735 & 451577 & 273 & 505 & \\
\hline & \multicolumn{6}{|c|}{$\mathrm{SEM}^{\mathrm{y}}=1.7$} & \multicolumn{6}{|c|}{$\mathrm{SEM}^{\mathrm{y}}=0.30$} & \multicolumn{5}{|c|}{$\mathrm{SEM}^{\mathrm{y}}=30.9$} \\
\hline $\begin{array}{l}\text { Significant } \\
\text { effects }^{x}\end{array}$ & \multicolumn{6}{|c|}{$\begin{array}{c}\mathrm{C}, \mathrm{A}, \mathrm{T} \\
\mathrm{C} \times \mathrm{A}, \mathrm{C} \times \mathrm{T}\end{array}$} & \multicolumn{6}{|c|}{$\mathrm{P}, \mathrm{A}, \mathrm{T}, \mathrm{C} \times \mathrm{T}$} & & $\begin{array}{r}\mathrm{C}, \mathrm{A} \\
\mathrm{C} \times \mathrm{T},\end{array}$ & ${ }^{T} \times T$ & & \\
\hline
\end{tabular}

${ }^{2}$ To compare the subplot effects of storage type and duration within production method $(\mathrm{n}=6$ 'McIntosh

'To compare the main plot effects of production method at each storage-time combination $(\mathrm{n}=$

xFactors significant at $P<0.05$, where $\mathrm{C}=$ cultivar, $\mathrm{P}=$ production method, $\mathrm{A}=$ storage atmosphere, and $\mathrm{T}=$ storage time.

Table 3. Effects of production method on the sensory attributes' of 'McIntosh' and 'Cortland' apples at harvest and after 4 months of storage.

\begin{tabular}{|c|c|c|c|c|c|c|c|c|c|c|c|c|c|c|c|}
\hline \multirow{4}{*}{$\begin{array}{l}\text { Source of } \\
\text { variation }\end{array}$} & \multicolumn{15}{|c|}{ Sensory attributes } \\
\hline & \multicolumn{3}{|c|}{ Firmness } & \multicolumn{3}{|c|}{ Juiciness } & \multicolumn{3}{|c|}{ Sweetness } & \multicolumn{3}{|c|}{ Tartness } & \multicolumn{3}{|c|}{ Off-flavor } \\
\hline & \multirow[b]{2}{*}{ Initial } & \multicolumn{2}{|c|}{4 months } & \multirow[b]{2}{*}{ Initial } & \multicolumn{2}{|c|}{4 months } & \multirow[b]{2}{*}{ Initial } & \multicolumn{2}{|c|}{4 months } & \multirow[b]{2}{*}{ Initial } & \multicolumn{2}{|c|}{4 months } & \multirow[b]{2}{*}{ Initial } & \multicolumn{2}{|c|}{4 months } \\
\hline & & $\overline{\text { Air }}$ & $\mathrm{CA}$ & & Air & $\mathrm{CA}$ & & Air & CA & & Air & $\overline{\mathrm{CA}}$ & & Air & $\mathrm{CA}$ \\
\hline \multicolumn{16}{|l|}{ McIntosh } \\
\hline Organic & 4.7 & 2.4 & 4.0 & 4.8 & 2.4 & 4.0 & 3.5 & 4.1 & 3.3 & 5.6 & 3.2 & 4.7 & 1.8 & 2.8 & 1.7 \\
\hline Conventional & 3.5 & 2.3 & 4.0 & 5.0 & 2.3 & 4.0 & 4.1 & 3.9 & 3.1 & 4.4 & 2.8 & 4.5 & 2.1 & 2.4 & \\
\hline \multicolumn{16}{|l|}{ Cortland } \\
\hline Organic & 3.7 & 2.7 & 4.6 & 4.2 & 2.7 & 4.5 & 4.2 & 4.4 & 3.6 & 4.5 & 2.9 & 4.7 & 1.5 & 2.4 & 1.6 \\
\hline Conventional & 4.5 & 2.7 & 4.6 & 4.6 & 2.7 & 4.6 & 3.9 & 3.9 & 3.6 & 4.4 & & 4.3 & 1.4 & 2.6 & 1.5 \\
\hline $\mathrm{SEM}^{\mathrm{y}}$ & 0.26 & & 13 & 0.30 & 0. & 14 & 0.19 & 0 . & 16 & 0.42 & 0. & 20 & 0.20 & 0.1 & \\
\hline $\begin{array}{c}\text { Significant } \\
\text { effects }^{x}\end{array}$ & $C \times P$ & & A & $\ldots$ &. & A & --. & $t$ & & ... & t & 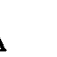 & $\ldots$ & C, & \\
\hline
\end{tabular}

${ }^{2}$ Ratings $1=$ none/very soft, $9=$ extreme/very hard.

${ }^{y}$ At harvest $\mathrm{n}=30$ (10 panelists $\times 3$ reps), df $=4$; at 4 months $\mathrm{n}=30$, df $=12$.

'Factors significant at $P<0.05$, where $\mathrm{C}=$ cultivar, $\mathrm{P}=$ production method, and $\mathrm{A}=$ storage atmosphere.

ation that were significant at $P<0.05$ are discussed.

Production method had no significant effect on penetrometer measurements of firmness (Table 2). 'Cortland' apples were always firmer than 'McIntosh', regardless of production method or storage conditions, and CA-stored apples were always firmer than air-stored apples, regardless of production method or cultivar. After 4 months of storage and 7 days at $20 \pm 1 \mathrm{C}$, the firmness of apples from both production methods within each cultivar and storage atmosphere decreased to similar levels. Regardless of production method, the firmness of air-stored 'McIntosh' decreased to $31 \pm 1 \mathrm{~N}$ and airstored 'Cortland' decreased to $48 \pm 1 \mathrm{~N}$, while CA-stored 'McIntosh' decreased to 52 $\pm 1 \mathrm{~N}$ and CA-stored 'Cortland' decreased to $57 \pm 1 \mathrm{~N}$

Sensory panelists perceived organically grown 'McIntosh' to be firmer than conventionally grown 'McIntosh' at harvest (Table 3 ) but perceived no significant difference in the firmness of 'Cortland' apples at harvest. Panelists commented that organically grown 'McIntosh' tasted starchier and seemed less mature than conventionally grown 'McIntosh'. Organically grown 'McIntosh' had a starch index of 3.7 ( 1 = maximum starch, $9=$ no starch) compared with 4.7 ( SEM = 0.25 ) for conventionally grown 'McIntosh', supporting the panelists' impression that the organically grown apples were less mature. Thus, the difference in firmness perceived by the panelists may have been an effect of starch content and/or fruit maturity. Regardless of cultivar or storage, after 4 months of storage, production method had no significant effect on firmness (Table 3 ).

No significant differences due to production method were perceived by the sensory panelists in juiciness of apples at harvest and after 4 months of storage (Table 3). Apples from both production methods that had been stored in CA were perceived as juicier than air-stored apples.

Organically grown apples had higher SSC than conventionally grown apples at harves and after storage (Table 2) and after 7 days at $20 \pm 1 \mathrm{C}$ (data not shown). This effect was consistent for both cultivars, although 'Cortland' apples had higher SSC than 'McIntosh' apples and CA-stored apples had higher SSC than air-stored apples. There are few reports of increased SSC in organically grown fruits and vegetables. Schuphan (1974) observed that vegetables grown with com- post manure have more total sugars than those grown with mineral fertilizers. Zeiger (1978) found SSC to be inversely related to apple yield per tree. However, we found no significant difference in apple yield per tree due to production method; also, differences in SSC due to production method still existed when apple yield per tree was used as a covariate.

Production method had no significant effect on the TA of the apples (Table 2). Regardless of production method or storage conditions, 'McIntosh' had higher TA than 'Cortland', and, regardless of production method or cultivar, CA-stored apples had higher TA than air-stored apples. After 4 months of storage and 7 days at $20 \pm 1 \mathrm{C}$, the TA of apples from both production methods within each cultivar and storage atmosphere had decreased to similar levels. The TA of air-stored 'McIntosh' decreased to 356 $\pm 18 \mathrm{mg} / 100 \mathrm{ml}$ and TA of air-stored 'Cortland' decreased to $336 \pm 21 \mathrm{mg} / 100 \mathrm{ml}$, while TA of CA-stored 'McIntosh' decreased to $535 \pm 22 \mathrm{mg} / 100 \mathrm{ml}$ and that of CA-stored 'Cortland' decreased to $503 \pm 16$ $\mathrm{mg} / 100 \mathrm{ml}$.

Sensory panelists perceived no significant differences in sweetness, tartness, or off-fla- 
vor of organically and conventionally grown apples at harvest or after storage (Table 3). CA-stored apples from both production methods were perceived as being sweeter and more tart, while air-stored apples from both production methods developed a slight offflavor.

Although production method influenced SSC, the sensory panelists perceived no difference in the intensity of sweetness between organically and conventionally produced apples. In a study using 'Cox's Orange Pippin' apples, Richardson (1986) found no consistent relationships between sensory sweetness and tartness and chemical determinations of sugar and malate, respectively. Organically and conventionally grown apples may have been perceived as similar because the ratios of sugars (SSC) to acids (TA) were similar for both production methods.
Overall, this study showed no consistent quality or sensory differences between organically and conventionally grown 'McIntosh' and 'Cortland' apples. Differences tended to be influenced more by cultivar and storage conditions than by production method.

\section{Literature Cited}

Consumer and Corporate Affairs Canada. 1988. Guide for food manufacturers and advertisers. Consumer \& Corporate Affairs Canada, Hull, Quebec.

DeEll, J. 1991. A postharvest study of organically and conventionally grown apples. MSc Thesis, Dalhousie Univ., N.S.

Genstat 5 Committee. 1987. Genstat 5 reference manual. Oxford Univ. Press, New York.

Organic Crop Improvement Assn. 1989. OCIA certification standards. Canadian OCIA, Inc., Belle Plaine, Saskatchewan.
Reinken, G. 1987. Eight years trials with vegetables and apples of bio-dynamic growing in comparison with conventional management. Gesunde Pflanzen 39:59-64, 241-251.

Richardson, A. 1986. The effects of herbicide soil management systems and nitrogen fertilizer on the eating quality of Cox's Orange Pippin apples. J. Hort. Sci. 61:447456.

Schuphan, W. 1974. Nutritional value of crops as influenced by organic and inorganic fertilizer treatments. Qual. Plant - Plant Foods Human Nutr. 23:333-358.

Weissenborn, K. and H-J. Dammann. 1974. Organische Düngung auf schwerem abgeschobenen Marschboden zu Cox und Golden Delicious auf M9. Mitteillungen des Obstbauversuchsringes des Alten Landes 29: 192-200.

Zeiger, D. 1978. Nitrogen fertilizing and pruning of apple trees as they affect yield, fruit quality and tree growth in North Carolina. North Carolina Agr. Expt. Sta. Tech. Bul. 254. 